\title{
Entry at the trans-Face of the Golgi
}

\author{
Suzanne R. Pfeffer \\ Department of Biochemistry, Stanford University School of Medicine, Stanford, California 94305-5307 \\ Correspondence: pfeffer@stanford.edu
}

\begin{abstract}
The trans-Golgi network (TGN) receives a select set of proteins from the endocytic pathwayabout $5 \%$ of total plasma membrane glycoproteins (Duncan and Kornfeld 1988). Proteins that are delivered include mannose 6-phosphate receptors (MPRs), TGN46, sortilin, and various toxins that hitchhike a ride backward through the secretory pathway to intoxicate cells after they exit into the cytoplasm from the endoplasmic reticulum (ER). This article will review work on the molecular players that drive protein transport from the endocytic pathway to the TGN. Distinct requirements have revealed multiple routes for retrograde transport; in addition, the existence of multiple, potential coat proteins and/or cargo adaptors imply that multiple vesicular transfers are likely involved. Several comprehensive reviews have appeared recently and should be sought for additional details (Bonifacino and Rojas 2006; Johannes and Popoff 2008).
\end{abstract}

\section{CARGOES TRANSPORTED}

Early studies of retrograde transport of proEteins to the TGN focused on MPRs that carry newly made lysosomal enzymes from the Golgi to early endosomes and then return to the Golgi after passing through late endosomes (Ghosh et al. 2003). The Vps10 protein carries out an analogous function in yeast, returning to the Golgi after delivering vacuolar hydrolases to prevacuolar compartments (Marcusson et al. 1994). This yeast sorting process is not based on mannose 6-phosphate recognition. Like the mammalian prohormone processing enzyme, furin, the yeast Kex2 protease also cycles between Golgi and prelysosomal compartments. In addition to these cargo receptors and protein modifying enzymes, the SNARE proteins involved in these transport events also recycle to the Golgi. A longer list of protein cargoes is provided elsewhere (Johannes and Popoff 2008). Accurate identification of retrograde cargoes has relied on their biochemical modification by Golgi resident enzymes such as sialyltransferase and tyrosine sulfotransferase that are localized uniquely in the TGN, or specific genetic blocks in this pathway. For example, depletion of the Retromer ${ }^{1}$ protein, Vps26, led to mislocalization of the normally Golgi localized, BACE 2 enzyme in endosomes (He et al. 2005). Wingless protein is also mislocalized in cells harboring mutant Retromer proteins (Port and Basler 2010). This is good evidence that these proteins shuttle between endosomes and the

\footnotetext{
${ }^{1}$ Retromer: a complex of proteins that is important for transport from endosomes to the Golgi complex. In yeast, it contains Vps26p, Vps29p, Vps35p, Vps17p, and Vps5p. In mammals, it contains Vps26, Vps29, Vps35, SNX1, SNX2, SNX5, and SNX6.
}

Editors: Graham Warren and James Rothman

Additional Perspectives on The Golgi available at www.cshperspectives.org

Copyright (C) 2011 Cold Spring Harbor Laboratory Press; all rights reserved; doi: 10.1101/cshperspect.a005272

Cite this article as Cold Spring Harb Perspect Biol 2011;3:a005272 


\section{S.R. Pfeffer}

Golgi complex. (Some misassignments may have been made when morphology was the sole criterion for return to the Golgi, as late endosomes and recycling endosomes are located very close to the Golgi and without the use of distinguishing marker proteins, localizations can be incorrect.) Shiga toxin, cholera toxin, and ricin are well-documented cargoes that move from early endosomes to the TGN.

\section{COATS IN RETROGRADE TRANSPORT}

Early studies of clathrin function suggested that clathrin in complex with its $\mathrm{AP} 2^{2}$ adaptor mediated endocytosis, whereas clathrin in complex with its $\mathrm{AP}^{3}$ adaptor participated in the formation of MPR containing transport vesicles at the TGN (Robinson 2004). Thus, it was a surprise when MPRs were found to accumulate in early endosomes in cells lacking AP1 adaptor proteins (Meyer et al. 2000). This suggested that AP1 functions in the retrieval of MPRs back to the Golgi and later work suggested a role for AP1 at both the Golgi and at endosomes. The subsequent discovery of a role for so-called $\mathrm{GGA}^{4}$ proteins as Golgi export cargo adaptors provided a possible explanation: the GGA adaptors might cover for loss of AP1 function at the Golgi, and the accumulation of MPRs in early endosomes of these cells would then reflect the additional requirement for AP1 at that location (Doray et al. 2002; Puertollano et al. 2003). Live cell video microscopy showed that $65 \%$ of MPR-containing tubules leaving the TGN are AP1 decorated (Waguri et al. 2003), consistent with AP1 functioning at two locations (Doray et al. 2002; Hirst et al. 2009). The AP1-binding, epsin $R^{5}$ protein (Hirst et al. 2003; Mills et al. 2003) is also needed for retrograde transport

\footnotetext{
${ }^{2} \mathrm{AP} 2$ adaptor complex is a heterotetrameric complex that links cargo to clathrin-mediated endocytosis.

${ }^{3} \mathrm{AP} 1$ adaptor complex is a heterotetrameric complex that links cargo to clathrin mediated Golgi export.

${ }^{4}$ Golgi-localized, gamma adaptin ear-containing, ARFbinding protein family.

${ }^{5} \mathrm{~A}$ clathrin-coated vesicle-enriched, $70 \mathrm{kD}$ protein that binds phosphatidylinositol-4-phosphate, clathrin, and the gamma appendage domain of the clathrin adaptor protein complex 1 (AP1).
}

of Shiga toxin, TGN46, and MPRs (Saint-Pol et al. 2004).

Retromer proteins are also important for the segregation of retrograde cargo at early endosomes (Arighi et al. 2004; Seaman 2004; Carlton et al. 2004), and an important question for future investigation is how Retromer functions in relation to AP1 and clathrin. The Johannes lab (Popoff et al. 2007) has suggested a model in which clathrin sorts cargoes into tubules that form at the early endosome and then use Retromer for subsequent transport to the Golgi. This model invokes flat patches of clathrin (and presumably AP1 adaptors) to segregate different cargo classes into distinct tubule types. In this case, clathrin acts first but in close proximity to Retromer; all of this sorting begins in early endosomes. Tubule formation is likely to be facilitated by the EHD3 protein ${ }^{6}$ (Naslavsky et al. 2009), which acts in conjunction with the Rab11 effector, Rab11-FIP2 to link to a myosin motor. The recent identification of a role for Rab7 GTPase in Retromer recruitment onto endosomes (Rojas et al. 2008; Seaman et al. 2009) suggests that Retromer functions at the intersection between early and late endosomes. This new finding could represent a second cargo selection step at a compartment that is later in nature than the one housing clathrin patches.

TIP47 protein also functions as yet another cargo adaptor that is essential for recognition of MPRs at late endosomes for their subsequent retrograde transport to the Golgi (Diaz and Pfeffer 1998). Depletion of TIP47 leads to enhanced degradation of MPRs in cells, and TIP47 is required for in vitro transport of MPRs from endosomes to the TGN. Association of TIP47 with endosome membranes is blocked by antiMPR cytoplasmic domain antibodies, and binding requires specific residues in each of the MPRs (Orsel et al. 2000). Importantly, TIP47 expression actually stimulates MPR transport to the TGN in transfected cells (Carroll et al. 2001; Sincock et al. 2003). These

${ }^{6}$ eps15 homology (EH) domain containing protein designated EHD3. 
data strongly support a model in which TIP47 acts as a cargo-selection device for MPR retrograde transport.

TIP47 also binds the late endosomal Rab9 GTPase (Carroll et al. 2001). Importantly, Rab9 binding increases the affinity with which TIP47 binds CI-MPR cytoplasmic domains. Moreover, the interaction of TIP47 with Rab9 is needed for its ability to stimulate the transport of MPRs from late endosomes to the TGN (Hanna et al. 2002), and expression of a mutant TIP47 protein that cannot bind Rab9 changes the morphology of late endosomes (Barbero et al. 2002). These data indicate that TIP47 is recruited onto late endosomes by Rab9, which thereby participates in cargo collection by the TIP47 protein. The importance of TIP47 in Rab9 function is further highlighted by the unexpected finding that depletion of TIP47 enhances turnover of Rab9 protein (Ganley et al. 2004). TIP47 acts in strict coordination with the late endosomal Rab9 GTPase, providing an additional sorting step at late endosomes.

The simplest explanation for a requirement for multiple cargo adaptors is the possibility that multiple vesicle transfers take place. Clathrin and Retromer likely sort cargo at an early or intermediate endosome; later, TIP47-dependent steps would segregate MPRs from cargo to be degraded in lysosomes.

Recent work from Brodsky and coworkers indicates that AP1-mediated retrograde transport may use two distinct clathrin isoforms. Unlike the predominant $\mathrm{CHC} 17$ clathrin heavy chain isoform, the related $\mathrm{CHC} 22$ clathrin heavy chain binds preferentially to AP1 and AP3 and seems to be important for retrograde transport of several cargoes including MPRs (Esk et al. 2010). This study suggested that there are two clathrin-dependent steps at early endosomes: $\mathrm{CHC17}$ and $\mathrm{SNX}^{7}$ would act before CHC22 to segregate cargo into tubules. A subsequent step would require Syntaxin $10^{8}$ (see

\footnotetext{
${ }^{7}$ Sorting nexin- 1.

${ }^{8} \mathrm{~A}$ class of SNARE protein implicated in docking and fusion of vesicles at target membranes.
}

below). The precise nature of these intermediates and the number of fusion events involved will require further study. Interestingly, TGN $46^{9}$ does not use this pathway for its steady state localization at the TGN; as described below, a number of molecular distinctions in retrograde transport support the existence of multiple pathways for return to the Golgi.

\section{RAB AND SNARE PROTEINS IN RETROGRADE TRANSPORT}

SNARE proteins are discussed in greater depth in an article by Malsam and Söllner (2011). Shiga toxin, cholera toxin, and ricin use a SNARE complex containing STX6, STX16, Vtila, and the v-SNAREs, VAMP3 or VAMP4 (Mallard et al. 2002) for their delivery to the Golgi. Shiga toxin transport also requires Rab6A and Rab43 GTPases (Del Nery et al. 2006; Fuchs et al. 2007) but not Rab9 GTPase (Wilcke et al. 2000; Iversen et al. 2001). Rab21 and Rab22a may also be involved (Fuchs et al. 2007).

Late endosome to TGN transport relies on the Rab9 GTPase (Lombardi et al. 1993; Riederer et al. 1994), as well as Rab6 GTPase, which functions in tether localization at the TGN (see the following) (Burguete et al. 2008). Strong support for the existence of distinct routes to the TGN came from the identification of a distinct requirement for Syntaxin 10 (STX10) for MPR recycling to the TGN in human cells, where it functions as part of a STX16, Vti1A, and VAMP3-containing SNARE complex. Although TGN46 and cholera toxin require STX6, MPR recycling does not. An additional SNARE complex comprised of GS15, Syntaxin 5, GS28, and YKT6 was also found to be important for Shiga toxin transport (Tai et al. 2004; Mallard et al. 2002), but this complex may function at a retrograde transport step within the Golgi complex, rather than for initial arrival at the TGN. Figure 1 summarizes some of the molecular distinctions between the two pathways.

\footnotetext{
${ }^{9} \mathrm{~A}$ trans-Golgi network localized protein of unknown
} function. 
S.R. Pfeffer

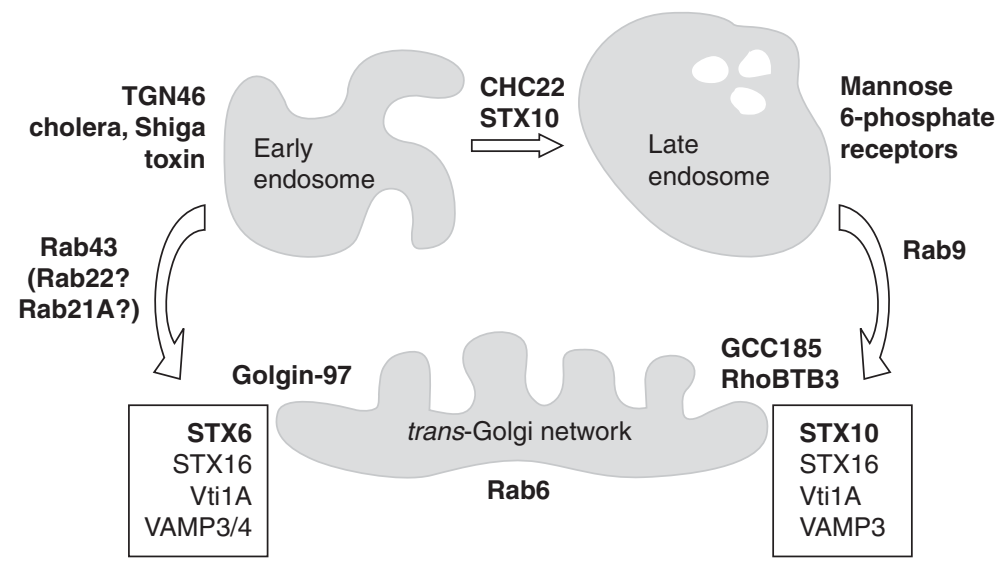

Figure 1. Multiple routes of protein transport from the endocytic pathway to the trans-Golgi network. For details, see text.

\section{TETHERING PROTEINS AT THE TGN}

Tethering complexes can be divided into two groups: multisubunit complexes based on the yeast Exocyst, or long, coiled coil proteins such as the Golgins that decorate the Golgi complex (Sztul and Lupashin 2006; Short et al. 2005). Soluble tethers needed for transport to the TGN were first reported in yeast (Conibear and Stevens 2000 ) as the VFTor GARP complex comprised of the Vps52/53/53 complex and Vps51 proteins. These proteins bound directly to a t-SNARE, Tlg1 needed for retrograde transport. In human cells, the GARP complex is required for the retrograde transport of MPRs, TGN46, and Shiga toxin (Pérez-Victoria et al. 2008). As first shown for the yeast complex, human GARP (Liewen et al. 2005) binds to the TGN-localized t-SNAREs, Syntaxin 6, Syntaxin 16, and the Vamp4 v-SNARE that mediate retrograde transport, strongly suggesting a role for the GARP complex in SNARE remodeling and/or localization (Pérez-Victoria and Bonifacino 2009).

Of the longer, coiled coil class of tethering proteins, there are at least five representatives anchored at the TGN: four GRIP domain tethers (Golgin 245, Golgin 97, GCC185, and GCC88) and TMF/ARA160 (Yamane et al. 2007). The former class use their carboxy-terminal GRIP domains as a binding site for the TGN localized, small GTPase, Arl1 (Panic et al. 2003; Munro
2005; Munro 2011); they are thought to form parallel homodimers that partition between the cytosol and the Golgi membrane surface (Luke et al. 2005). Golgin 245 and Golgin 97 bind Arl1 tightly; GCC185 binds Arl1 with enhanced affinity in the presence of Rab6 GTPase (Burguete et al. 2008; Pfeffer 2009). (Recently, Houghton et al. 2009 questioned a role for Rab6 in GCC185 binding. Major gaps in their logic are summarized in Pfeffer 2009.) That these proteins function as transport vesicle tethers comes from experiments in which they are depleted from cells: for example, GCC185 depletion leads to accumulation of MPRs in peripheral transport vesicles (Reddy et al. 2006; Derby et al. 2007).

Depletion and overexpression phenotypic analyses have been used to show that the putative tethering proteins, Golgin-97 ( $\mathrm{Lu}$ et al. 2004) and Golgin-245 (Yoshino et al. 2005) are both important for Shiga toxin retrograde transport whereas Golgin 97 does not seem to be needed for MPR recycling (Reddy et al. 2006). In contrast, TGN38 (but not Shiga toxin) uses the GCC88 protein (Lieu et al. 2007) (Table 1). It is interesting to note that all retrograde cargoes seem to use the GARP complex, but the cargoes distinguish themselves in terms of their requirements for individual, extended coiled coil tethers. Table 1 summarizes the varied requirements for distinct classes of putative vesicle tethers. 


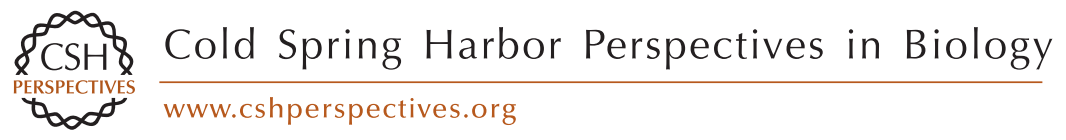

Table 1. Functional distinctions between TGN Golgins and Tethering factors

\begin{tabular}{|c|c|c|c|c|c|c|}
\hline Cargo & $\begin{array}{l}\text { Golgin245 } \\
\text { (p230) }\end{array}$ & Golgin97 & GCC185 & GCC88 & TMF & GARP complex \\
\hline $\begin{array}{l}\text { Endogenous MPRs } \\
\text { (not hybrid proteins with MPR } \\
\text { cytoplasmic domains) }\end{array}$ & & $\begin{array}{l}\text { Not needed } \\
\text { (Reddy et al. } \\
2006)\end{array}$ & $\begin{array}{l}\text { Essential } \\
\text { (Reddy et al. 2006; } \\
\text { Derby et al. 2007) } \\
\text { Binds Rab9, Rab6 } \\
\text { and STX16, needed } \\
\text { for this step (Ganley } \\
\text { et al. 2008) }\end{array}$ & & & $\begin{array}{l}\text { Essential } \\
\text { (Pérez-Victoria 2008) Binds } \\
\text { STX10, needed for this step } \\
\text { (Liewen et al. 2005) }\end{array}$ \\
\hline Shiga Toxin B & $\begin{array}{l}\text { Essential } \\
\text { (Yoshino } \\
\text { et al. 2005) }\end{array}$ & $\begin{array}{l}\text { Essential } \\
\text { (Lu et al. 2004) } \\
\text { MBoC 15, 4426 }\end{array}$ & & $\begin{array}{l}\text { Not needed } \\
\text { (Lieu et al. 2007) } \\
\text { MBoC }\end{array}$ & & $\begin{array}{l}\text { Essential } \\
\text { (Pérez-Victoria et al. 2008, 2009) } \\
\text { Binds STX6, needed for this step }\end{array}$ \\
\hline TGN38/46 & & & $\begin{array}{l}\text { Not needed } \\
\text { (Derby 2007) }\end{array}$ & $\begin{array}{l}\text { Essential } \\
\text { for Syntaxin } 6 \\
\text { localization (Lieu } \\
\text { et al. 2007), MBoC } \\
\text { (Lieu and Gleeson } \\
\text { 2010) }\end{array}$ & $\begin{array}{l}\text { (Fridmann-Sirkis } \\
\text { et al. 2004) }\end{array}$ & $\begin{array}{l}\text { Essential } \\
\text { (Pérez-Victoria et al. 2008) }\end{array}$ \\
\hline
\end{tabular}


S.R. Pfeffer

\section{RhoBTB3 ATPase}

A Rab9-interaction yeast two-hybrid screen identified RhoBTB3 as a Rab9 binding partner (Reddy et al. 2006). RhoBTB3 is an unusual member of the Rho family of GTPases. First, it is $69 \mathrm{kDa}$ instead of $\sim 25 \mathrm{kD}$; it is comprised of an amino-terminal Rho domain and a carboxyterminal BTB (Bric-a-brac, Tramtrack, Broadcomplex) domain (Ramos et al. 2002; Salas Vidal et al. 2005). The amino-terminal Rho domain is not a GTPase like other Rho family members, but is instead an ATPase (Espinosa et al. 2009). Rab9 binds to RhoBTB3 at the carboxyl terminus, downstream of the BTB domain. Like GCC185, RhoBTB3 is localized to the Golgi and depletion of the protein disperses the MPR into peripheral, Rab9-positive vesicles. Unlike GCC185 depletion, however, the Golgi appears swollen. It is not yet known why loss of this protein yields a distinct phenotype. Both ATP hydrolysis and Rab9 binding capacity are needed to restore MPR retrograde transport in RhoBTB3-depleted cultured cells (Espinosa et al. 2009).

In membrane trafficking events, ATPases are used to disassemble SNARE proteins (NSF), ESCRT assemblies (Vps4) or clathrin coats (Hsc70). We therefore tested if RhoBTB3 might interact with the cargo-adaptor protein, TIP47 that might be part of a vesicle coat. Native blue gel electrophoresis revealed that RhoBTB3 exists in a stable complex of $\sim 475 \mathrm{kDa}$ with TIP47 on dodecyl maltoside-solubilized membranes. In the presence of ATP and Rab9, TIP47 is released from this complex (Espinosa et al. 2009). This supports a model in which any TIP47 that remains on Rab9-positive transport vesicles can be removed on arrival of the vesicle at the Golgi. After TIP47 removal, SNARE pairing can occur and the vesicle fuses with the Golgi.

\section{PHYSICAL STRUCTURE OF THE TGN}

The TGN generates transport vesicles bound for distinct domains of the plasma membrane as well as early endosomes. Thus, it will contain distinct domains that participate in the formation of these distinct transport vesicle types. High voltage electron microscopic tomography indicates that the TGN may be comprised of as many as three cisternal types (C5, C6, and C7) (Mogelsvang et al. 2004) (Fig. 2); all of these extend tubules, and the presence of budding vesicles and tubular extensions implies a role in exit from the Golgi. The trans-most cisternae (C7) displays clathrin-coated profiles, whereas the others display only nonclathrin-coated buds and tubules (Ladinsky et al. 1994). Of interest is the distinct morphology between the transmost cisternae and those preceding it: the transmost compartment is not fenestrated and seems more defined by vesicle budding profiles. The molecular basis for morphological fenestration will be important to determine. Clathrin is implicated in the Golgi export of MPRs that carry newly made lysosomal enzymes from the Golgi to prelysosomes. The domain of the TGN to which MPRs return to is unknown, but it seems reasonable to propose that they return to the same domain (or near to the domain) that is used for MPR exit.

Gleeson and colleagues have reported that the TGN tethers appear localize to distinct domains of the TGN. Derby et al. (2004) showed that cells overexpressing GCC185 segregated sialyltransferase into a domain distinct from that occupied by GCC88; TGN38 may be more closely linked to the GC88 compartment (Luke et al. 2003), consistent with it's requirement for that tethering factor for retrograde transport (Lieu et al. 2007). This suggests that the TGN itself is specialized; predicted would be the existence of distinct domains to receive distinct sets of cargoes. Physical mapping of these distinct TGN domains will be important: a prediction is that Syntaxin 10 will segregate with GCC185. That the GARP complex appears to engage all classes of TGN Golgins suggests that it may function more in TGN SNARE complex remodeling than "vesicle catching," per se.

Entirely unknown is the relationship between Golgin subdomains and these three morphological TGN domains. It will be interesting to determine how close a TGN domain containing GCC185 and the Syntaxin 10 SNARE complex, organized to receive MPR cargo from late endosomes, resides in relation to a clathrin domain that repackages that receptor for export from the Golgi. 
Entry at the trans-Face of the Golgi
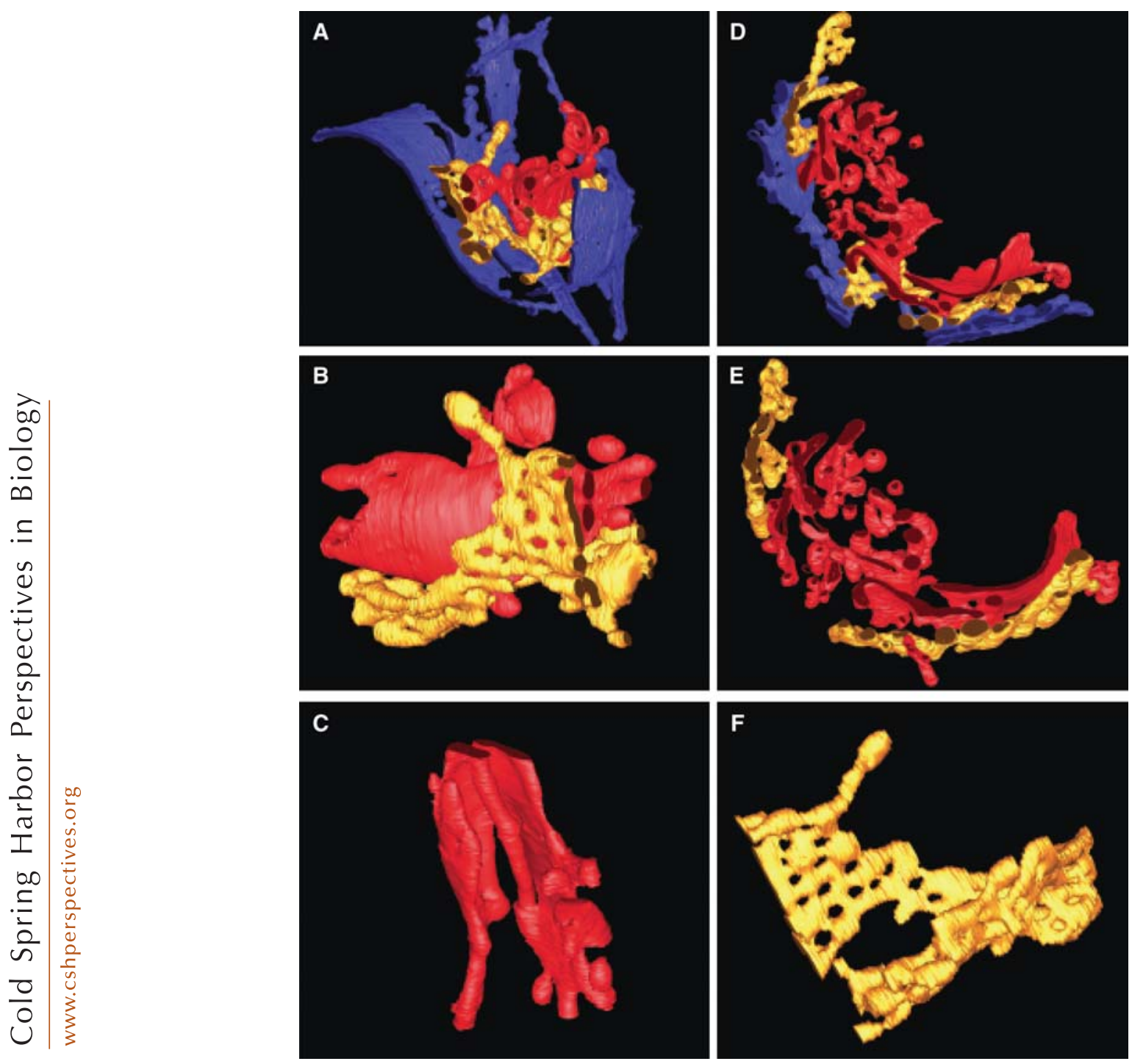

Figure 2. Three dimensional electron microscopic tomography reveals a complex architecture for the TGN. The three trans-most cisternae are shown in dark blue, gold, and red. The clathrin coated, trans-most cisternae is solid, unlike the fenestrated, penultimate trans-cisternae. Adapted from Mogelsvang et al. (2004) and reprinted with permission from John Wiley \& Sons (C) 2004.

\section{HIGHER ORDER GOLGI ORGANIZATION BY TGN TETHERS}

Two recent reports indicate that TGN Golgins can bind multiple Rab GTPases across their lengths (Sinka et al. 2008; Hayes et al. 2009). This led Munro to propose that the Golgins function to retain nascent transport vesicles that bud from cisternae in close proximity to their Golgi targets (Munro 2011). Because Golgins have the potential to reach distances as long as the entire width of a Golgi stack, they are predicted to mediate long range interactions (Hayes et al. 2009). Still to be explained is why depletion of any one of the for GRIP domain Golgins leads to Golgi stack fragmentation 
S.R. Pfeffer
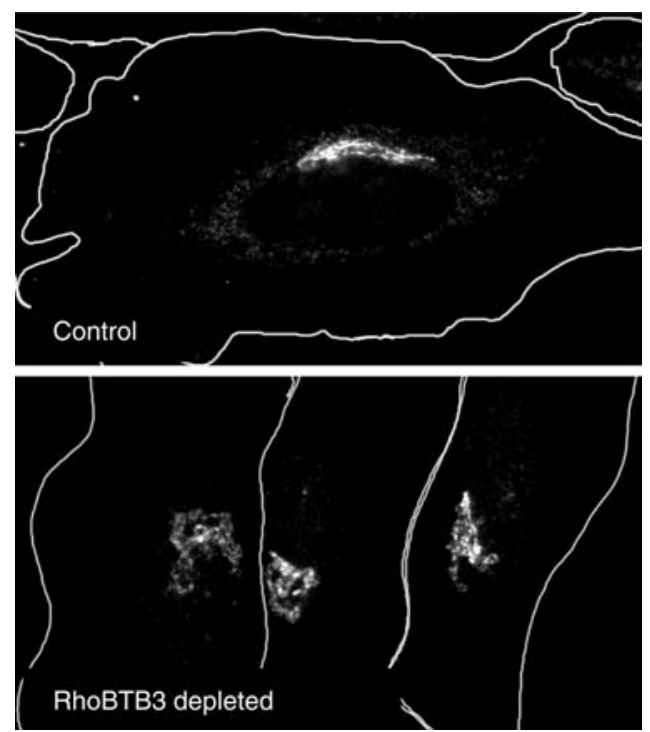

Figure 3. Depletion of the putative vesicle tethering factor, RhoBTB3 causes the Golgi to appear altered. Shown is the localization of GCC185 in control or RhoBTB3 depleted cells. For details, see Espinosa et al. (2009).

(Fig. 3). The simplest explanation is that Golgi ribbon integrity depends on multiple, low affinity, trans-interactions. The precise roles of the GRIP domain Golgins in relation to the GARP complex will be important to determine, and is covered in detail in Munro 2011.

\section{MICROTUBULES AT THE TGN}

Efimov et al. (2007) showed recently that noncentrosomal microtubules emanate directly from the Golgi complex, and are linked there by binding to GCC185-associated CLASP protein. This provides an express route for transport vesicles inbound to the Golgi: using cytoplasmic dynein, they can be transported directly to the tethering factor that will facilitate their engagement with the appropriate SNARE complex. It is not yet known whether GCC185 is the only GRIP domain Golgin that can bind to CLASP; also not yet known is where CLASP interacts with GCC185, and whether all GCC185 molecules have CLASP bound. There is no question that terminating a motor track with a
Golgi-associated tether will enhance the efficiency of vesicle transfers to their TGN targets.

\section{CONCLUDING REMARKS}

Retrograde protein transport is essential for normal cellular homeostasis: it permits efficient recycling of MPRs back to the Golgi to ensure proper lysosomal enzyme targeting. However, it is also important for normal neurological function: amyloid precursor (APP) is transported by the sortilin related protein, SORL1 (Anderson et al. 2005) which, like the BACE APP processing enzyme, undergoes Retromer dependent, retrograde transport (see Skinner and Seaman 2009 for review). Indeed, polymorphisms in the SORL1 gene are linked to late onset Alzheimer's disease (Rogaeva et al. 2007). Although great progress has been made in the identification of proteins that participate in retrograde transport, much work is still needed to understand where on the TGN retrograde vesicles arrive and how that site(s) relates to domains used for transport vesicle formation and secretion. Why are there so many cargo adaptors, and how many fission and fusion reactions are involved? These issues are sure to be examined by a number of laboratories over the next several years.

\section{REFERENCES}

Amessou M, Fradagrada A, Falguières T, Lord JM, Smith DC, Roberts LM, Lamaze C, Johannes L. 2007. Syntaxin 16 and syntaxin 5 are required for efficient retrograde transport of several exogenous and endogenous cargo proteins. J Cell Sci 120: 1457-1468.

Andersen OM, Reiche J, Schmidt V, Gotthardt M, Spoelgen R, Behlke J, von Arnim CA, Breiderhoff T, Jansen P, Wu X, et al. 2005. Neuronal sorting protein-related receptor sorLA/LR11 regulates processing of the amyloid precursor protein. Proc Natl Acad Sci 102: 13461-13466.

Arighi CN, Hartnell LM, Aguilar RC, Haft CR, Bonifacino JS. 2004. Role of the mammalian Retromer in sorting of the cation-independent mannose 6-phosphate receptor. J Cell Biol 165: 123-133.

Barbero P, Bittova L, Pfeffer SR. 2002. Visualization of Rab9mediated vesicle transport from endosomes to the transGolgi in living cells. J Cell Biol 156: 511-518.

Bonifacino JS, Rojas R. 2006. Retrograde transport from endosomes to the trans-Golgi network. Nat Rev Mol Cell Biol 7: 568-579. 
Burguete AS, Fenn TD, Brunger AT, Pfeffer SR. 2008. Rab and Arl GTPase family members cooperate in the localization of the golgin GCC185. Cell 132: 286-298.

Carlton J, Bujny M, Peter BJ, Oorschot VM, Rutherford A, Mellor H, Klumperman J, McMahon HT, Cullen PJ. 2004. Sorting nexin-1 mediates tubular endosome-toTGN transport through coincidence sensing of highcurvature membranes and 3-phosphoinositides. Curr Biol 14: 1791-1800.

Carroll KS, Hanna J, Simon I, Krise J, Barbero P, Pfeffer SR. 2001. Role of Rab9 GTPase in facilitating receptor recruitment by TIP47. Science 292: 1373-1376.

Conibear E, Cleck JN, Stevens TH. 2003. Vps51p mediates the association of the GARP (Vps52/53/54) complex with the late Golgi t-SNARE Tlg1p. Mol Biol Cell 14: $1610-1623$.

Conibear E, Stevens TH. 2000. Vps52p, Vps53p, and Vps54p form a novel multisubunit complex required for protein sorting at the yeast late Golgi. Mol Biol Cell 11: 305-323.

Del Nery E, Miserey-Lenkei S, Falguières T, Nizak C, Johannes L, Perez F, Goud B. 2006. Rab6A and Rab6A' GTPases play non-overlapping roles in membrane trafficking. Traffic 7: 394-407.

Derby MC, Lieu ZZ, Brown D, Stow JL, Goud B, Gleeson PA. 2007. The trans-Golgi network golgin, GCC185, is required for endosome-to-Golgi transport and maintenance of Golgi structure. Traffic 8: 758-773.

Derby MC, van Vliet C, Brown D, Luke MR, Lu L, Hong W, Stow JL, Gleeson PA. 2004. Mammalian GRIP domain proteins differ in their membrane binding properties and are recruited to distinct domains of the TGN. J Cell Sci 117: 5865-5874.

Díaz E, Pfeffer SR. 1998. TIP47: a cargo selection device for mannose 6-phosphate receptor trafficking. Cell 93: 433-443.

Doray B, Ghosh P, Griffith J, Geuze HJ, Kornfeld S. 2002. Cooperation of GGAs and AP-1 in packaging MPRs at the trans-Golgi network. Science 297: 1700-1703.

Duncan JR, Kornfeld S. 1988. Intracellular movement of two mannose 6-phosphate receptors: return to the Golgi apparatus. J Cell Biol 106: 617-628.

Efimov A, Kharitonov A, Efimova N, Loncarek J, Miller PM, Andreyeva N, Gleeson P, Galjart N, Maia AR, McLeod IX, et al. 2007. Asymmetric CLASP-dependent nucleation of noncentrosomal microtubules at the trans-Golgi network. Dev Cell 12: 917-930.

Esk C, Chen CY, Johannes L, Brodsky FM. 2010. The clathrin heavy chain isoform $\mathrm{CHC} 22$ functions in a novel endosomal sorting step. J Cell Biol 188: 131-144.

Espinosa EJ, Calero M, Sridevi K, Pfeffer SR. 2009. RhoBTB3: a Rho GTPase-family ATPase required for endosome to Golgi transport. Cell 137: 938-948.

Fridmann-Sirkis Y, Siniossoglou S, Pelham HR. 2004. TMF is a golgin that binds Rab6 and influences Golgi morphology. BMC Cell Biol 5: 18.

Fridmann-Sirkis Y, Kent HM, Lewis MJ, Evans PR, Pelham HR. 2006. Structural analysis of the interaction between the SNARE Tlg1 and Vps51. Traffic 7: 182-190.

Fuchs E, Haas AK, Spooner RA, Yoshimura S, Lord JM, Barr FA. 2007. Specific Rab GTPase-activating proteins define the Shiga toxin and epidermal growth factor uptake pathways. J Cell Biol 177: 1133-1143.

Ganley IG, Espinosa E, Pfeffer SR. 2008. A syntaxin 10-SNARE complex distinguishes two distinct transport routes from endosomes to the trans-Golgi in human cells. J Cell Biol 180: 159-172.

Ganley IG, Carroll K, Bittova L, Pfeffer S. 2004. Rab9 GTPase regulates late endosome size and requires effector interaction for its stability. Mol Biol Cell 15: 5420-5430.

Ghosh P, Dahms NM, Kornfeld S. 2003. Mannose 6-phosphate receptors: new twists in the tale. Nat Rev Mol Cell Biol 4: 202-212.

Goud B, Gleeson PA. 2010. TGN golgins, Rabs and cytoskeleton: regulating the Golgi trafficking highways. Trends Cell Biol 20: 329-336.

Hanna J, Carroll K, Pfeffer SR. 2002. Identification of residues in TIP47 essential for Rab9 binding. Proc Natl Acad Sci 99: 7450-7454.

Hayes GL, Brown FC, Haas AK, Nottingham RM, Barr FA, Pfeffer SR. 2009. Multiple Rab GTPase binding sites in GCC185 suggest a model for vesicle tethering at the transGolgi. Mol Biol Cell 20: 209-217.

He X, Li F, Chang WP, Tang J. 2005. GGA proteins mediate the recycling pathway of memapsin 2 (BACE). J Biol Chem 280: 11696-11703.

Hirst J, Motley A, Harasaki K, Peak Chew SY, Robinson MS. 2003. EpsinR: an ENTH domain-containing protein that interacts with AP-1. Mol Biol Cell 14: 625-641.

Hirst J, Sahlender DA, Choma M, Sinka R, Harbour ME, Parkinson M, Robinson MS. 2009. Spatial and functional relationship of GGAs and AP-1 in Drosophila and HeLa cells. Traffic 10: 1696-1710.

Houghton FJ, Chew PL, Lodeho S, Goud B, Gleeson PA. 2009. The localization of the Golgin GCC185 is independent of Rab6A/A' and Arl1. Cell 138: 787-794.

Iversen TG, Skretting G, Llorente A, Nicoziani P, van Deurs B, Sandvig K. 2001. Endosome to Golgi transport of ricin is independent of clathrin and of the Rab9- and Rab11-GTPases. Mol. Biol Cell 12: 2099-2107.

Johannes L, Popoff V. 2008. Tracing the retrograde route in protein trafficking. Cell 135: 1175-1187.

Ladinsky MS, Kremer JR, Furcinitti PS, McIntosh JR, Howell KE. 1994. HVEM tomography of the trans-Golgi network: structural insights and identification of a lacelike vesicle coat. J Cell Biol 127: 29-38.

Ladinsky MS, Mastronarde DN, McIntosh JR, Howell KE. Staehelin LA. 1999. J Cell Biol 144: 1135-1149.

Lieu ZZ, Gleeson PA. 2010. Identification of different itineraries and Retromer components for endosome-toGolgi transport of TGN38 and Shiga toxin. Eur J Cell Biol 89: 379-393.

Lieu ZZ, Derby MC, Teasdale RD, Hart C, Gunn P, Gleeson PA. 2007. The golgin GCC88 is required for efficient retrograde transport of cargo from the early endosomes to the trans-Golgi network. Mol Biol Cell 18: 4979-4991.

Lieu ZZ, Lock JG, Hammond LA, La Gruta NL, Stow JL, Gleeson PA. 2008. A trans-Golgi network golgin is required for the regulated secretion of TNF in activated macrophages in vivo. Proc Natl Acad Sci 105: 3351-3356.

Liewen H, Meinhold-Heerlein I, Oliveira V, Schwarzenbacher R, Luo G, Wadle A, Jung M, Pfreundschuh M, 


\section{S.R. Pfeffer}

Stenner-Liewen F. 2005. Characterization of the human GARP (Golgi associated retrograde protein) complex. Exp Cell Res 306: 24-34.

Lock JG, Hammond LA, Houghton F, Gleeson PA, Stow JL. 2005. E-cadherin transport from the trans-Golgi network in tubulovesicular carriers is selectively regulated by golgin-97. Traffic 6: 1142-1156.

Lombardi D, Soldati T, Riederer MA, Goda Y, Zerial M, Pfeffer SR. 1993. Rab9 functions in transport between late endosomes and the trans-Golgi network. EMBO J 12: 677-682.

Lu L, Tai G, Hong W. 2004. Autoantigen Golgin-97, an effector of Arll GTPase, participates in traffic from the endosome to the trans-Golgi network. Mol Biol Cell 15: 4426-4443.

Luke MR, Houghton F, Perugini MA, Gleeson PA. 2005. The trans-Golgi network GRIP-domain proteins form alphahelical homodimers. Biochem J 388: 835-841.

Luke MR, Kjer-Nielsen L, Brown DL, Stow JL, Gleeson PA 2003. GRIP domain-mediated targeting of two new coiled-coil proteins, GCC88 and GCC185, to subcompartments of the trans-Golgi network. J Biol Chem 278: 4216-4226.

Mallard F, Antony C, Tenza D, Salamero J, Goud B, Johannes L. 1998. Direct pathway from early/recycling endosomes to the Golgi apparatus revealed through the study of shiga toxin B-fragment transport. J Cell Biol 143: 973-990.

Mallard F, Tang BL, Galli T, Tenza D, Saint-Pol A, Yue X, Antony C, Hong W, Goud B, Johannes L. 2002. Early/ recycling endosomes-to-TGN transport involves two SNARE complexes and a Rab6 isoform. J Cell Biol 156: 653-664.

Malsam J, Söllner TH. 2011. Organization of the SNAREs within the Golgi stack. Cold Spring Harb Perspect Biol doi: 10.1101/cshperspect.a005249.

Marcusson EG, Horazdovsky BF, Cereghino JL, Gharakhanian E, Emr SD. 1994. The sorting receptor for yeast vacuolar carboxypeptidase Y is encoded by the VPS10 gene. Cell 77: 579-586.

Meyer C, Zizioli D, Lausmann S, Eskelinen EL, Hamann J, Saftig P, von Figura K, Schu P. 2000. mulA-adaptindeficient mice: lethality, loss of AP-1 binding and rerouting of mannose 6-phosphate receptors. EMBO J 19: 2193-2203.

Mills IG, Praefcke GJ, Vallis Y, Peter BJ, Olesen LE, Gallop JL, Butler PJ, Evans PR, McMahon HT. 2003. EpsinR: an AP1/clathrin interacting protein involved in vesicle trafficking. J Cell Biol 160: 213-222.

Mogelsvang S, Marsh BJ, Ladinsky MS, Howell KE. 2004 Predicting function from structure: 3D structure studies of the mammalian Golgi complex. Traffic 5: 338-345.

Munro S. 2005. The Arf-like GTPase Arll and its role in membrane traffic. Biochem Soc Trans 33: 601-605.

Munro S. 2011. The Golgin coiled-coil proteins of the Golgi apparatus. Cold Spring Harb Perspect Biol doi: 10.1101/ cshperspect.a005256.

Naslavsky N, McKenzie J, Altan-Bonnet N, Sheff D, Caplan S. 2009. EHD3 regulates early-endosome-to-Golgi transport and preserves Golgi morphology. J Cell Sci 122: 389-400.
Orsel JG, Sincock PM, Krise JP, Pfeffer SR. 2000. Recognition of the 300-kDa mannose 6-phosphate receptor cytoplasmic domain by $47-\mathrm{kDa}$ tail-interacting protein. Proc Natl Acad Sci 97: 9047-9051.

Panic B, Whyte JR, Munro S. 2003. The ARF-like GTPases Arllp and Arl3p act in a pathway that interacts with vesicle-tethering factors at the Golgi apparatus. Curr Biol 13: 405-410.

Pérez-Victoria FJ, Bonifacino JS. 2009. Dual roles of the mammalian GARP complex in tethering and SNARE complex assembly at the trans-golgi network. Mol Cell Biol 29: 5251-5263.

Pérez-Victoria FJ, Mardones GA, Bonifacino JS. 2008. Requirement of the human GARP complex for mannose 6-phosphate-receptor-dependent sorting of cathepsin D to lysosomes. Mol Biol Cell 19: 2350-2362.

Pérez-Victoria FJ, Schindler C, Magadán JG, Mardones GA, Delevoye C, Romao M, Raposo G, Bonifacino JS. 2010. Ang2/Fat-free Is a Conserved Subunit of the Golgi-associated Retrograde Protein (GARP) Complex. Mol Biol Cell doi: 101091/mbcE10-05-0392.

Pfeffer SR. 2009. Multiple routes of protein transport from endosomes to the trans-Golgi network. FEBS Lett 583: 3811-3816.

Popoff V, Mardones GA, Tenza D, Rojas R, Lamaze C, Bonifacino JS, Raposo G, Johannes L. 2007. The Retromer complex and clathrin define an early endosomal retrograde exit site. J Cell Sci 120: 2022-2031.

Port F, Basler K. 2010. Wnt trafficking: new insights into Wnt maturation, secretion and spreading. Traffic 11: 1265-1271.

Puertollano R, van der Wel NN, Greene LE, Eisenberg E, Peters PJ, Bonifacino JS. 2003. Morphology and dynamics of clathrin/GGA1-coated carriers budding from the trans-Golgi network. Mol Biol Cell 14: 1545-1557.

Ramos S, Khademi F, Somesh BP, Rivero F. 2002. Genomic organization and expression profile of the small GTPases of the RhoBTB family in human and mouse. Gene 298: 147-157.

Reddy JV, Burguete AS, Sridevi K, Ganley IG, Nottingham RM, Pfeffer SR. 2006. A functional role for the GCC185 golgin in mannose 6-phosphate receptor recycling. Mol Biol Cell 17: 4353-4363.

Riederer MA, Soldati T, Shapiro AD, Lin J, Pfeffer SR. 1994. Lysosome biogenesis requires Rab9 function and receptor recycling from endosomes to the trans-Golgi network. J Cell Biol 125: 573-582.

Robinson MS. 2004. Adaptable adaptors for coated vesicles. Trends Cell Biol 14: 167-174.

Rogaeva E, Meng Y, Lee JH, Gu Y, Kawarai T, Zou F, Katayama T, Baldwin CT, Cheng R, Hasegawa H, et al. 2007. The neuronal sortilin-related receptor SORL1 is genetically associated with Alzheimer disease. Nat Genet 39: 168-177.

Rojas R, van Vlijmen T, Mardones GA, Prabhu Y, Rojas AL, Mohammed S, Heck AJ, Raposo G, van der Sluijs P, Bonifacino JS. 2008. Regulation of Retromer recruitment to endosomes by sequential action of Rab5 and Rab7. J Cell Biol 183: 513-526.

Saint-Pol A, Yélamos B, Amessou M, Mills IG, Dugast M, Tenza D, Schu P, Antony C, McMahon HT, Lamaze C, 
et al. 2004. Clathrin adaptor epsinR is required for retrograde sorting on early endosomal membranes. Dev Cell 6: $525-538$.

Salas-Vidal E, Meijer AH, Cheng X, Spaink HP. 2005. Genomic annotation and expression analysis of the zebrafish Rho small GTPase family during development and bacterial infection. Genomics 86: 25-37.

Seaman MN, Harbour ME, Tattersall D, Read E, Bright N. 2009. Membrane recruitment of the cargo-selective Retromer subcomplex is catalysed by the small GTPase Rab7 and inhibited by the Rab-GAP TBC1D5. J Cell Sci 122: $2371-2382$.

Seaman MN. 2004. Cargo-selective endosomal sorting for retrieval to the Golgi requires Retromer. J Cell Biol 165: 111-122.

Short B, Haas A, Barr FA. 2005. Golgins and GTPases, giving identity and structure to the Golgi apparatus. Biochem Biophys Acta 1744: 383-395.

Sincock PM, Ganley IG, Krise JP, Diederichs S, Sivars U, O'Connor B, Ding L, Pfeffer SR. 2003. Self-assembly is important for TIP47 function in mannose 6-phosphate receptor transport. Traffic 4: 18-25.

Sinka R, Gillingham AK, Kondylis V, Munro S. 2008. Golgi coiled-coil proteins contain multiple binding sites for Rab family G proteins. J Cell Biol 183: 607-615.

Skinner CF, Seaman MNJ. 2009. The role of retromer in neurodegenerative disease. In Intracellular traffic and neurodegenerative disorders: Research and perspectives in
Alzheimer's disease (ed. P. St. George-Hyslop et al.), pp. 125-140. Springer-Verlag, Berlin, Heidelberg.

Sztul E, Lupashin V. 2006. Role of tethering factors in secretory membrane traffic. Am J Physiol Cell Physiol 290: C11-C26.

Tai G, Lu L, Wang TL, Tang BL, Goud B, Johannes L, Hong W. 2004. Participation of the syntaxin 5/Ykt6/GS28/ GS15 SNARE complex in transport from the early/recycling endosome to the trans-Golgi network. Mol Biol Cell 15: 4011-4022.

Waguri S, Dewitte F, Le Borgne R, Rouillé Y, Uchiyama Y, Dubremetz JF, Hoflack B. 2003. Visualization of TGN to endosome trafficking through fluorescently labeled MPR and AP-1 in living cells. Mol Biol Cell 14: 142-155.

Wilcke M, Johannes L, Galli T, Mayau V, Goud B, Salamero J. 2000. Rab11 regulates the compartmentalization of early endosomes required for efficient transport from early endosomes to the trans-golgi network. J Cell Biol 151: 1207-1220.

Yamane J, Kubo A, Nakayama K, Yuba-Kubo A, Katsuno T, Tsukita S. Tsukita S. 2007. Functional involvement of TMF/ARA160 in Rab6-dependent retrograde membrane traffic. Exp Cell Res 313: 3472-3485.

Yoshino A, Setty SR, Poynton C, Whiteman EL, Saint-Pol A, Burd CG, Johannes L, Holzbaur EL, Koval M, McCaffery JM, et al. 2005. TGolgin-1 (p230, golgin-245) modulates Shiga-toxin transport to the Golgi and Golgi motility towards the microtubule-organizing centre. J Cell Sci 118: $2279-2293$. 


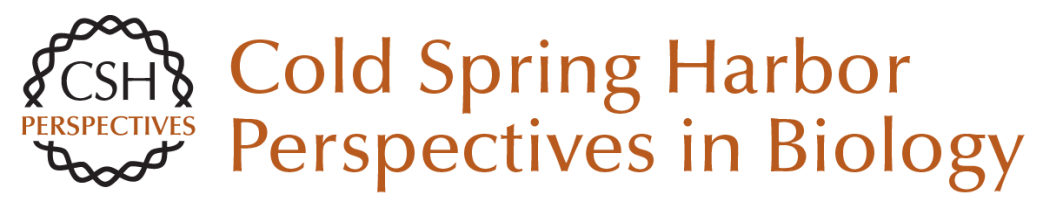

\section{Entry at the trans-Face of the Golgi}

Suzanne R. Pfeffer

Cold Spring Harb Perspect Biol 2011; doi: 10.1101/cshperspect.a005272 originally published online January 26, 2011

\section{Subject Collection The Golgi}

Structure of Golgi Transport Proteins

Daniel Kümmel and Karin M. Reinisch

\section{Golgi Biogenesis}

Yanzhuang Wang and Joachim Seemann

Golgi Glycosylation and Human Inherited

Diseases

Hudson H. Freeze and Bobby G. Ng

Models for Golgi Traffic: A Critical Assessment

Benjamin S. Glick and Alberto Luini

\section{Architecture of the Mammalian Golgi} Judith Klumperman

Evolution and Diversity of the Golgi Mary J. Klute, Paul Melançon and Joel B. Dacks

Evolutionary Forces Shaping the Golgi

Glycosylation Machinery: Why Cell Surface

Glycans Are Universal to Living Cells Ajit Varki

Golgi Positioning

Smita Yadav and Adam D. Linstedt
Golgi and Related Vesicle Proteomics: Simplify to Identify Joan Gannon, John J.M. Bergeron and Tommy Nilsson

Organization of SNAREs within the Golgi Stack Jörg Malsam and Thomas H. Söllner

Golgi during Development Weimin Zhong

Entry and Exit Mechanisms at the cis-Face of the Golgi Complex Andrés Lorente-Rodríguez and Charles Barlowe

COPI Budding within the Golgi Stack Vincent Popoff, Frank Adolf, Britta Brügger, et al.

Mechanisms of Protein Retention in the Golgi David K. Banfield

The Golgin Coiled-Coil Proteins of the Golgi

Apparatus Sean Munro

Signaling at the Golgi Peter Mayinger

For additional articles in this collection, see http://cshperspectives.cshlp.org/cgi/collection/

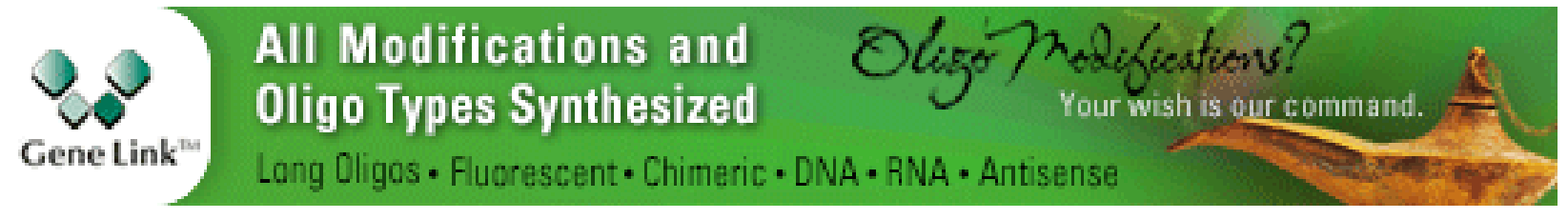

Copyright @ 2011 Cold Spring Harbor Laboratory Press; all rights reserved 